\title{
Exploring the Nexus Between Foreign Aid and Human Capital Development in Nigeria
}

\author{
Johnbosco Ozigbo Dennis Ewubare \\ Rivers State University, P.M.B. 5080, Port Harcourt, Nigeria
}

\begin{abstract}
This paper utilizes country-specific time series data over the period 1990-2017 and Autoregressive Distributive Lag (ARDL) model to estimate the relationship between and human capital development in Nigeria. The specific objectives focused on the impacts of official development assistance (ODA), broad-based grants and technical cooperation grants on public investments in education and healthcare. The Phillips-Perron unit root test results reveal that the variables are mixed integrated with evidence of levels and first difference stationarity. The mixed order of the integration in the series necessitated the application of ARDL bounds test for cointegration and the results indicate that the variables in each of the models have long run relationship. Findings from the estimated ARDL models reveal that lagged values ODA exert significant positive impact on public investment in education in the short run. Both the first and third lag of broad-based grant has significant negative relationship with public investment in education in the short run. The long run result revealed that ODA and technical cooperation grants have significant positive relationship with public investment in education. 1 percent increase in ODA and technical cooperation grants increases public investment in education by 4.289 percent and 0.829 percent respectively. It was further observed that the contemporaneous value of ODA has positive relationship with public healthcare investment in the short run. 1 percent increase in ODA inflow increases public healthcare investment by 1.099 percent. Additionally, there is more than proportionate increase in public investment in healthcare to the tune of 3.179 percent following 1 percent increase in ODA in the long run. Therefore, it is recommended among others that policy makers and donor countries/agencies should prioritize the education sector in the disbursement of foreign aid with a view to achieving the fourth Sustainable Development Goal (SDG) which is to ensure inclusive and quality education for all and promote lifelong learning.
\end{abstract}

Keywords: Human development, education, healthcare, ODA, grants, ARDL and Nigeria.

DOI: $10.7176 / \mathrm{JESD} / 10-7-05$

Publication date: April $30^{\text {th }} 2019$

\subsection{Introduction}

Human capital development involves the transformation of the population into productive labour force capable of driving the process of economic development. Essentially, it focuses on prioritizing investments in healthcare and education as core indices of human development in order to improve the productive capacity of relatively unskilled individuals to enable them contribute meaningfully to the rapid and sustained growth of the economy. Ewubare (2018) observed that economic planning strategies broadly tend to prioritize human capital development through investment in education, training and healthcare. As outlined in the Mosley (1986) micro-macro paradox, foreign aid is considered as an enabler of human development in the aid recipient economies following its perceived effectiveness in addressing key development challenges. Staicu \& Barbulescu (2017) argued that foreign aid is expected to achieve better result in terms of improving the living conditions of the population through quality healthcare delivery and education rather than boosting economic growth.

Sachs (2005) equally perceived the inflows of aid to developing economies as necessary condition for eradicating poverty by 2025. However, Easterly (2006) criticized the aid process on the grounds that little or no results in terms of poverty reduction has been achieved compared to the amount received as aid. Collier (2007) held similar view with Easterly regarding the ineffectiveness of foreign aid in driving the process of development. The issue of aid ineffectiveness has continued to receive widespread attention in development economics literature considering the fact that foreign aid has remained an outstanding source of capital for low income countries (Ozigbu, 2018). Contrary to the aid ineffectiveness claims by Easterly (2006) and Collier (2007) amongst others, Bakare (2011) opined that international aid tends to foster sustainable development through the transfer of new technologies, skills and modern productive techniques. This assertion aligns with the public interest hypothesis of aid-development nexus in the aid recipient countries. Again, it supports the assertion of the Organization of Economic Cooperation and Development (OECD) in 1999 that foreign aid is good for industrial development, employment generation and overall economic turnaround.

As one of the key segments of the world's development cooperation, foreign aid can take the form of bilateral aid, multilateral aid, tied and untied aid. It can further be dis aggregated into Official Development Assistance (ODA), grants and technical cooperation grants amongst others. The ODA has been adjudged as the most outstanding form of foreign aid in international economics literature given that (i) it is provided for foreign governments or their national agencies (ii) it can be in the form of a grant or a loan with an interest rate less than 
the market rate and (iii) it is mostly targeted at improving the standard of living and welfare general welfare in low income countries (see Staicu \& Barbulescu 2017).

The regional distribution of foreign aid indicates that the sub-Saharan (SSA) has remained a substantial destination of international aid compared to other regions of the world. However, the pace of human development in the SSA has largely remained sub-optimal. For instance, the human development index (HDI) for SSA in 2015 as reported by the United Nations Development Programme (UNDP, 2016) is 0.523 while that of East Asia Arab States, Europe, the Pacific, Central Asia, Latin America, the Caribbean and The south Asia ranged from 0.621 to 0.726. This suggests that the SSA has performed poorly in terms human development.

As evidenced in the official statistics of the World Bank, International Monetary Fund (IMF), the OECD Development Assistance Committee (DAC) and Central Bank of Nigeria (CBN), Nigeria has remained a notable destination of foreign aid since her political independence in 1960. Okon (2012) estimated the inflows to Nigeria between 1999 and 2007 as US\$6 Billion. The trend of net ODA as reported by the OECD (2016) increased from US\$ $1,293,720,000$ in 2008 to US $\$ 2,431,600,000$ in 2015. Despite the huge aid inflows to Nigeria, the pace of human development as captured by the HDI score which represents the country's achievements in healthcare, education and living standard has not been impressive as reported in figure 1 .

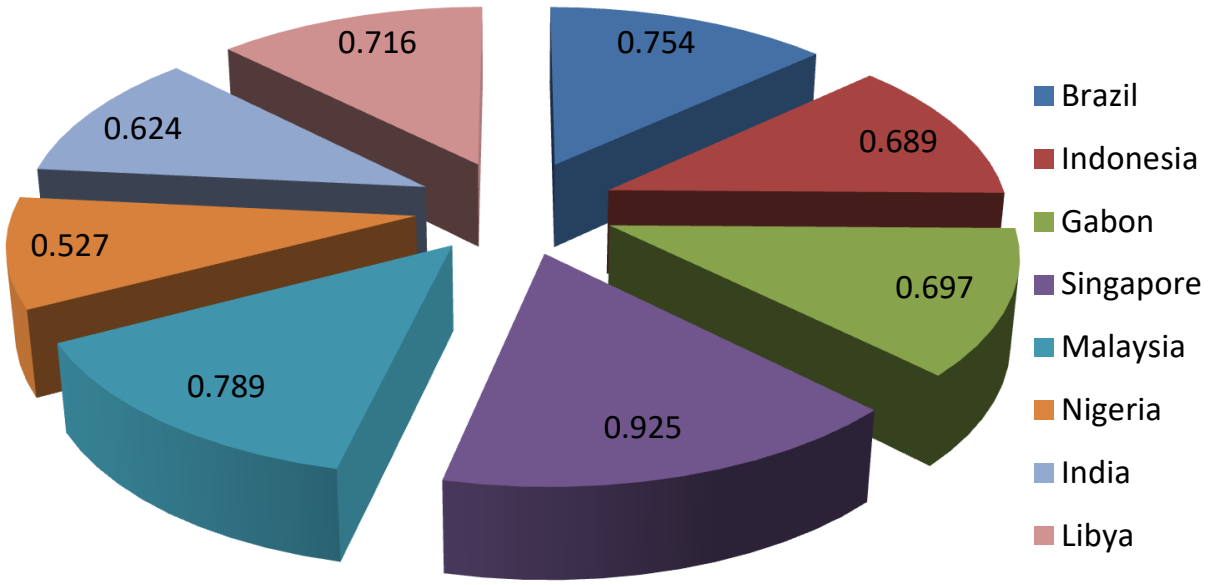

Figure 1: 2015 HDI score for Nigeria and other sampled countries

Source: Author's compilation based on data sourced from UNDP (2016) HDI report.

Figure 1 shows that Nigeria is associated with a HDI score of 0.527 in 2015, thus, it is classified as a low human development economy. On the other hand, Singapore has a HDI score of 0.925 and as such it is classified as very high human development country while Malaysia, Brazil and Libya fall under the category of high human development countries. The 2015 HDI scores for Indonesia, Gabon and India also surpassed that of Nigeria, thus earning them the status of medium human development economies. Based on the foregoing, this paper is designed to examine how inflows of foreign aid have helped in shaping the level of human capital formation with emphasis on investments in education and healthcare. It is also expected that this paper provide better understanding on how each of these cornerstones of human development have benefited from the inflows of foreign aid during the study period.

\section{Literature Review \\ 2.1 Theoretical Literature \\ 2.1.1 Harrod-Domar Model}

This model was developed by Harrod (1939) and Domar (1946) in an effort to provide more insights into the aidinvestment relationship and investment growth relationship. The Harrod-Domar model assumes that aid drives investment in developing economies following the prevalent savings-investment gap. For the reason, low income countries with common feature of capital-deficit often rely on international aid to advance their development process. Earlier studies (Rotarou \& Ueta 2009; Moreira, 2005) in the development economics demonstrated that savings-investment gap remains an impediment to economic prosperity in developing economies, thus, these 
countries tend to resort to foreign following its perceived positive spill-over effects on economic development.

Najeb (2014) argued that the Harrod-Domar model provides some insight into the growth dynamics following the assumption that increase in investment provides opportunity for additional growth. For this reason, low level of capital formation remains a major constraint to development of poor countries. The Harrod-Domar has been described as one of the foremost models in economic literature used for analyzing the drivers of economic growth in developing economies. Again, it has been adjudged as the foundation of development models used by some organizations such as the World Bank and International Monetary Fund (IMF) as it measures the investment considered necessary for a target growth rate. The model assumes that financing gap which defines the gap between required investment and available resources can be closed with international aid. Thus, the amount of foreign aid available to an economy determines the pace of economic growth.

Easterly (1999) described the Harrod-Domar model as the most widely applied growth model in economic history notwithstanding its focus on the link between short term investment and recession in the United States. Both theory and empirical evidences suggest that controversies exist on the aid-investment relationship and investment-growth relationship. For instance, Esaterly (2003) demonstrated empirically that a significant positive relationship exists between aid and investment in seventeen out of the eighty-eight sampled countries. The result further indicates that only six out of the seventeen countries show evidence of proportional relationship between investment and aid. It was also found by Easterly (2003) that investment-growth relationship is only proportional for one out 138 sampled countries. These results are evidence of the increasing aid fungibility partly attributed to the incidences of corruption, bad governance and poor institutional quality amongst others. Although the HarrodDomar model has been adjudged as one of the foremost models that shaped economic growth in developing economies, it has suffered some drawbacks. Griffin \& Enos (1970) observed that aid inflows as proposed by the Harrod-Domar model poses a threat the efficiency of capital output in the aid recipient economies given that the aid allocation process is often driven by political interest which tends to undermine its effectiveness. Additionally, Snowdon (2010) argued that the effectiveness of aid in driving the growth process tends to reduce following the perceived negative impact of aid on the Incremental Capital Output Ratio (ICOR).

\subsubsection{Three-Gap Model}

Bacha (1990) and Taylor (1994) developed the three-gap theory of development as an improvement to the twogap model. The major contribution of the model is the assumption of fiscal-gap. Thus, public investments in developing economies are believed to be constrained by fiscal gap often triggered by the insufficient domestic tax revenues. Consequently, the model assumes that these developing countries tend to leverage on foreign aid to overcome this fiscal challenge. Aid is important in narrowing fiscal gap and changing the equilibrium level of investment by raising private investment (Hanson \& Tarp 2000). The growing expenditure-revenue gap in developing economies makes them to resort to foreign aid as a reliable source of capital for developmental projects. Generally, Conchesta (2008) observed that the three gap model connotes the saving- investment gap, foreign exchange gap and fiscal gap. It is believed that the external source of funding, especially international aid plays a key role in bridging this fiscal gap. It has been established theoretically and empirically that inflows of international aid boost public investment in the core indices of human development such as healthcare delivery and education. This is believed to shape the pace of human capital formation and improve the overall marginal productivity of labour. Specifically, the "three-gap model" of foreign aid proposed to Bacha (1990) and Taylor (1990) is applied in this paper. The justification for the choice of this theory is based on its assumption that foreign aid is important in narrowing fiscal gap and boosting the level of investment in the key aspects of human development.

\subsection{Conceptualization of Human Capital Development}

Generally, human capital development involves building and sustaining the productive capacity of the population through investment in healthcare and education. Kanayo (2013) explained that investing in human capital development is critical as it is targeted at ensuring that the nation's human resource endowment is knowledgeable, skilled, productive and healthy to enable the optimal exploitation and utilization of other resources to engender growth and development. The UNDP Human Development Report in 1990 describes human capital development based on the achievements of a country on the three basic components of human development such as healthcare delivery, education and standard of living.

Based on UNDP context of human development, the core objective of development is the creation of an enabling environment for people to live long, healthy and productive lives. Specifically, healthcare delivery is measured by life expectancy while educational attainment is measured by the expected and mean years of schooling. Additionally, the standard of living is measured by the purchasing power, based on real GDP per capita often adjusted for the local cost of living. The OECD (2001) described human capital as the knowledge, skills, competencies, and attributes possessed by individuals that enhance the creation of personal, social and economic well-being. Investment in human capital proves productive when the educated labour force is optimally utilized to contribute and to accelerate the pace of economic activities through public policy.

Becker (2011) offered more encompassing view of human capital formation by describing it as gross 
investment in education, healthcare, training and other forms of capacity building that boost earnings, improve health, or contribute positively to the lifetime of an individual. Therefore, formation or accumulation of human capital and economic development for human welfare remain the major targets of economic policy pursued by each country. Kucharčíková, (2011) argued that human capital defines the factor which offers a specific character to every organization. In view of this, individuals are perceived as an important tool in organization for innovating, stimulating and making necessary changes as well as think creatively.

In modern economic literature, human capital formation is applied in classifying expenditure on human capital as investment rather than consumption. Thus, human capital is similar to physical means of production. Investment in human capital means all activities that influence future real income through the embedding of resources in people. This covers expenditure on education, training, health, information, and labour mobility. Among the generally agreed causal factors responsible for the impressive performance of the economy of most of the developed countries is huge commitment to human capital formation.

\subsection{Empirical Literature}

The role of foreign aid in driving human capital formation in the aid recipient economies has been an intense debate in recent time. Thus, many empirical studies have devoted attention to the aid-development nexus with controversial outcomes. Asiama \& Quartey (2009) offered some new and exclusive empirical evidence on the implication of aid on some selected welfare indicators in the sub-Saharan Africa. The study applied multivariate regression analysis and found that aggregate bilateral aid does not show a significant effect on the human development indicators and other welfare variables. However, disaggregated aid in the form of sector specific and programme aid tend to exert significant effect on the selected welfare indicators. On the basis of the findings, the study recommended that aid flows to the SSA should be scaled up but targeted at areas where its effectiveness mostly manifests.

Mohamed \& Mzee (2017) examined the impact of foreign aid on human development. The proxy for human development in the study is human development index (HDI). The empirical analysis which covered 124 developing countries from 1980 to 2013 relied on quantile multivariate regression. Generally, the result revealed that aid is positively linked to the human development index. It was obvious from the result that the effect is much greater in countries with low level of human development. Similarly, positive impact of aid on income, health, and education indices was also observed during the sample. In view of the findings, the study therefore concluded that development aid from donor countries is important in promoting human welfare.

Ishnazarov \& Cevik (2017) focused their study on the effectiveness of official development assistance (ODA) in promoting human development and economic progress of the recipient Organization of Islamic Cooperation (OIC) member countries between 2002 and 2015. The study particularly measures the impact of ODA classified by sectors on the components of Human Development Index (HDI) such as standards of living, life expectancy and education indices while controlling for the magnitude of civil violence, population growth, foreign direct investment, income, urbanization and regime type. It was found from the results that ODA is effective in influencing human development, having a greater and a more efficient impact on human development than other development instruments included in the analysis. The study equally reveals that civil violence is very harmful to HDI. In view of the findings, the study recommended for increase in ODA, especially, aid flows to health and education sectors, and intensify efforts to prevent and reduce civil violence to substantially attract foreign aid.

Tang \& Bundhoo (2017) offered a better understanding of the aid-growth in the sub-Saharan African (SSA) region. The study specifically examined the link between ODA and the economic growth rate in the SSA focusing on the ten largest recipients of international aid. These countries include Ethiopia, the Democratic Republic of Congo, Tanzania, Kenya, Côte d'Ivoire, Mozambique, Nigeria, Ghana, Uganda and Malawi. Multiple regression analysis was utilized as data analysis method and the result showed that aid by itself does not have significant impact on economic growth. The result further revealed that foreign aid enhances economic growth through investment and imports. This is an indication that foreign aid is a good ingredient for supplementing investment and imports requirements in the countries sampled. Overall, the study concludes that foreign aid is conditional on the economic, political and institutional environment of the recipient country. Hence, the study recommends that various governments, donor agencies, and policy makers should take into consideration these multiple aspects when undertaking aid-financing activities.

Maqsood \& Ullah (2014) empirically investigated the impact of foreign aid volatility on human development using Human Development Index as the dependent variable, whereas, foreign aid, foreign aid volatility and workers' remittances are utilized as independent variables. Various time series econometrics techniques were used for the empirical analysis and the results showed that foreign aid helps to promote human development as flow of money can be used to improve indicators of human development. The results further showed that there is no increase in human development index due to foreign aid volatility. Additionally, remittances were found not to exert any significant positive impact on human development index. The study was, therefore, considered as being helpful for policy makers to ensure consistency in policies related to foreign aid and remittances. 
Gillanders (2016) applied a vector autoregression model panel data driven analysis in examining the aid effectiveness hypothesis in the sub-Saharan African countries. This method was considered as it avoids the need for instrumental variables and allows one to analyze the effect of foreign aid on human development and on economic development simultaneously. It was evidence from the overall sample results that a small increase in economic growth is attributed to a fairly substantial aid shock. The size of the effect puts the result somewhere between the arguments of aid optimists and those of aid pessimists. It was obvious from the study that human development measured by the growth rate of life expectancy responds positively to aid shocks in countries studied.

Asongu \& Nwachukwu (2018) analyzed how increase in foreign aid influence inclusive human development in 53 African countries for the period, 2005-2012. The empirical analysis is based on the Generalised Method of Moments (GMM) to control for persistence in inclusive human development and instrumental variable Tobit regressions to control for simultaneity and the limited range in the dependent variable. The study mainly focused on 'humanitarian assistance', 'action on debt' 'aid for social infrastructure', 'aid to the productive sector', 'aid to the multi sector', 'aid for economic infrastructure' and 'programme assistance' as the key components of international aid. The GMM result shows evidence of a synergy effects from 'aid to the productive sector' and a positive net effect from 'programme assistance'. On the other hand, the Instrumental Variable Tobit regressions revealed that there is a synergy effect from 'aid for economic infrastructure' and a negative net impacts from 'aid for social infrastructure', 'aid to the productive sector' and human assistance. On the basis of the findings, the study recommended for efficient and effective utilization of aid in order to foster economic development.

\section{Materials and Method}

\subsection{Research Design}

Owing to the nature of this study, ex-post facto research design (after-the-fact research design) was adopted which describes a type of research design in which the empirical investigation starts after the fact has occurred without interference from the researcher. The choice of this research design was driven by the use of secondary data.

\subsection{Data Collection Methods and Sources}

This study employed secondary data which covered all the variables of interest. The characteristics of the data include annual time series covering the period of 1990 to 2018. The data were sourced from the World Development Indicators (WDI) and Central Bank of Nigeria Statistical Bulletin.

\subsection{Method of Data Analysis}

Following the dynamics of economic and financial time series which has remained very problematic in econometrics modelling and analysis, this paper employed the Autoregressive Distributed Lag (ARDL) model developed by Pesaran \& Shin (1999). The ARDL has, in the recent time, enjoyed widespread popularity in both theoretical and empirical econometrics due to its properties. The empirical validity of the ARDL was initially evaluated by Pesaran, Shin \& Smith (2001). As a dynamic regression model, the ARDL integrates the autoregressive and distributed-lag process in a single equation set-up. In accordance with its generic structure, the ARDL allows for the inclusion of lags of the regressand (dependent variable) as well as (and perhaps the current value) of other predictor variables, as explanatory variables.

Additionally, the ARDL is based on the assumption that the series are $\mathrm{I}(0), \mathrm{I}(1)$ or a combination of $\mathrm{I}(0)$ and I(1). Therefore, one of the precursors of the ARDL model is the determination of the order of integration of all the series through a unit root test. The rationale for this is to ensure that none of the series is $\mathrm{I}(2)$ so as to overcome the problem of spurious regression result. The choice of the ARDL in this study is justified by the relatively small size and its capacity to provide better insights into both long-run and short-run relationships among the variables of study. More so, descriptive statistics were applied to gain insights into the mean distribution of the series and their respective standard deviations amongst others. The pre-estimation tests conducted in the course of this study are explained as follows:

\subsubsection{Unit root test}

In this paprer, the Phillips-Perron method developed by Phillips and Perron (1988) was utilised to test for unit root in the underlying time series data. The Phillips-Perron test is an improved or adjusted Dickey-Fuller statistic, based on the Newey and West (1987) heteroscedasticity and serial correlation consistent covariance matrix estimator. As a non-parametric approach with respect to nuisance parameters, the Phillips-Perron test allows for possible heterogeneously distributed data (P hillips \& Perron, 1988). The general model for the Phillips-Perron test is of the form:

$\Delta Y_{t}=c_{0}+a_{1} \mathrm{t}+\sum_{i=1}^{b} b_{i} \Delta Y_{\mathrm{t}-\mathrm{i}}+\mu_{\mathrm{t}}$

Where $=Y_{t}=$ underlying economic time series under investigation, $\mathrm{Y}_{\mathrm{t}-1}=$ one period lag of the underlying economic under investigation, $b_{i}=$ regression estimate, $c=$ drift or constant term, $a_{t}=$ deterministic or linear trend, 
$\mathrm{u}_{\mathrm{t}}=$ stochastic term.

\subsubsection{Cointegration test}

The bounds test app roach to cointegration proposed by Pesaran and Shin (1999) was considered appropriated for testing for evidence of long run relationship amongst the underlying variables. Essentially, it is considered appropriate for handling times series data with fractional or mixed order of integration. As an autoregressive distributed lag (ARDL) method, the bounds test cointegration procedure tests the null hypothesis that no long-run relationship exists between or among the series against the alternative hypothesis that a long-run relationship exists. Its application is enabled whether the underlying series are $\mathrm{I}(0), \mathrm{I}(1)$ or a combination of both $\mathrm{I}(0)$ and $\mathrm{I}(1)$. In other words, it is applicable irrespective of whether the series are levels stationary, first difference stationary or mutually integrated. However, the bounds test procedure does not allow for variables with I(2) time series property.

\subsubsection{Breusch-Godfrey (BG) Serial Correlation Lagrange Multiplier LM Test}

The Breusch-Godfrey test for serial correlation is a Lagrange Multiplier (LM) test pioneered by Breusch (1978) and Godfrey (1978) as an improvement to the conventional Durbin Watson first order autocorrelation test. It was applied in test study to test the null hypothesis of no autocorrelation (Ho: LM $=0$ ) using asymptotic chi-square statistic distribution. The Breusch-Godfrey (BG) LM test statistic is computed as:

$$
\text { LM statistic }=n R^{2}
$$

Where: $n=$ number of observations included in the auxiliary regression test, $R^{2}=$ coefficient of determination from the estimated auxiliary regression. If the LM-cal is greater than the critical $X_{(p)}^{2}$, the null hypothesis is rejected, but if otherwise the null hypothesis is maintained.

\subsubsection{White Heteroscedasticity Test}

.This heteroscedasticity test proposed by White (1980) was applied in this paper to test the null hypothesis of no heteroscedasticity against the alternative hypothesis of heteroscedasticity. This test for heteroscedasticity allows for the introduction of the squares of the independent variables and the cross products of the independent variables in the auxiliary regression model, with the square of the residuals as the dependent variable.

\subsection{Model Specification}

This paper adopts the ARDL model anchored on the "three-gap model" of foreign aid credited to Bacha (1990) and Taylor (1990) which assumes foreign aid is important in narrowing fiscal gap and boosting the level of investment. The model set up for this paper involves the disaggregating human capital development into its two cornerstones- public investments in education and healthcare, and limiting the scope to country-specific analysis with Nigerian economy in view. Additionally, the indices of foreign aid included in the model was elaborated following the introduction of ODA, broad-based grants and technical corporation grants as the measures of aid inflows. Based on the foregoing, the ARDL models for this study are formally specified as:

$$
\begin{aligned}
& \triangle P E D_{t}=k_{1}+\sum_{i=1}^{q} \alpha_{1} \Delta P E D_{t-i}+\sum_{i=1}^{q} \alpha_{2} \Delta O D A_{t-i}+\sum_{i=1}^{q} \alpha_{3} \Delta G R T_{t-i}+\sum_{i=1}^{q} \alpha 4 T C G_{n t-i}+\theta_{1} P E D_{t-1}+\theta_{2} O D A_{t-1}+ \\
& \theta_{3} G R T_{t-1}+\theta_{4} T C G_{t-1}+e_{1 t} \\
& \triangle P H E_{t}=k_{2}+\sum_{i=1}^{q} \alpha_{1} \Delta P H E_{t-i}+\sum_{i=1}^{q} \alpha_{2} \Delta O D A_{t-i}+\sum_{i=1}^{q} \alpha_{3} \Delta G R T_{t-i}+\sum_{i=1}^{q} \alpha 4 T C G_{n t-i}+\theta_{1} P E D_{t-1}+\theta_{2} O D A_{t-1}+ \\
& \theta_{3} G R T_{t-1}+\theta_{4} T C G_{t-1}+e_{2 t}
\end{aligned}
$$

Where: PED and PHE denote public investments in education and health respectively.

ODA $=$ Official development assistance, GRT $=$ broad-based grant, $\mathrm{TCG}=$ Technical cooperation grants, $\mathrm{k}_{1}-\mathrm{k}_{2}$ represent the vector of intercepts, $\alpha_{1} \alpha_{4}=$ short-run coefficient of the predictor variables, $\theta_{1-} \theta_{4}=$ the long-run multipliers, $e_{1 t}$ and $e_{2 t}=$ stochastic variables

Following the underlying economic theory on aid-development relationship, the a priori expectations are of the

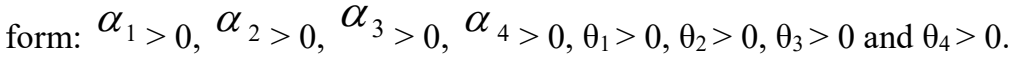

\section{Results and Discussion}

\subsection{Unit Root Test Results}

The empirical results of the unit root test conducted at 5 percent level of significance using Phillips and Perron (1988) method are showed in Table 1. 
Table 1: Phillips-Perron unit root test results

\begin{tabular}{lccl}
\hline & \multicolumn{2}{c}{ Levels test results } \\
\hline Series in the model & Adjusted t-statistic & Probability value & Stationarity status \\
LOG(PED) & -3.865 & 0.028 & Stationary \\
LOG(PHE) & -2.549 & 0.304 & Non-stationary \\
LOG(ODA) & -2.357 & 0.392 & Non-stationary \\
LOG(GRT) & -1.704 & 0.721 & Non-stationary \\
LOG(TCG) & -4.302 & 0.011 & Stationary \\
& First difference test results & \\
Series in the model & Adjusted t-statistic & Probability value & Stationarity status \\
LOG(PHE) & -5.041 & 0.002 & Stationary \\
LOG(ODA) & -4.120 & 0.017 & Stationary \\
LOG(GRT) & -5.043 & 0.002 & Stationary \\
\hline
\end{tabular}

Source: Author's compilation from the empirical data analysis

The Phillips-Perron approach formed basis for the unit root test and the results reported in Table 1 showed that public investment in education and technical cooperation grants are stationary at levels while the other variables are found to be non-stationary. Consequently, the non-stationary variables were further subjected to first difference test and the outcome of the test revealed that they depict a difference stationary process (DSP). The order of integration of the series based on the outcome of the unit root test is mixed. While public investment in education and broad-base grant are $\mathrm{I}(0)$, the rest of the series the models are all $\mathrm{I}(1)$. This finding is accordance with the results of Omoniyi \& Olawale (2015) for exchange rate, crude oil price and Inflation Rate in Nigeria and Türsoy (2017) for stock prices and exchange rates in Turkey amongst others. The mixed order of integration in the series necessitated the application of ARDL bounds test for cointegration.

\subsection{Results of the Bounds Cointegration tests}

The ARDL bounds cointegration tests results for each of the models are showed in Table 2.

Table 2: ARDL bounds test result for model 1

Null Hypothesis: No long-run relationships exist

Series: LOG(PED) LOG(ODA) LOG(GRT) LOG(TCG)

\begin{tabular}{lccccc}
\hline Test Statistic & Value & Number of regressors & \multicolumn{3}{c}{ Critical Value Bounds } \\
F-statistic & 91.924 & 3 & Significance level & Lower bound & Upper bound \\
& & & $10 \%$ & 2.72 & 3.77 \\
& & $5 \%$ & 3.23 & 4.35 \\
& & $1 \%$ & 4.29 & 5.61 \\
\hline
\end{tabular}

Source: Author's compilation from the empirical data analysis

Table 3: ARDL bounds test result for model 2

\begin{tabular}{lccccc}
\hline \multicolumn{2}{l}{ Null Hypothesis: No long-run relationships exist } \\
\multicolumn{3}{l}{ Series: LOG(PHE) LOG(ODA) LOG(GRT) LOG(TCG) } \\
\hline Test Statistic & Value & Number of regressors & \multicolumn{3}{c}{ Critical Bounds Value } \\
F-statistic & 22.818 & 3 & Significance level & Lower bound & Upper bound \\
& & $10 \%$ & 2.72 & 3.77 \\
& & $5 \%$ & 3.23 & 4.35 \\
& & $1 \%$ & 4.29 & 5.61 \\
\hline
\end{tabular}

Source: Author's compilation from the empirical data analysis

The result for model 1 reported in Table 2 indicates that the variables have long run relationship given that the computed F-statistic (91.924) is greater than the upper bound critical value (4.35). Similarly, the result for model 2 showed in Table 3 revealed that the variables are cointegrated. This followed the fact the calculated Fstatistic (22.818) is more than the upper bound critical value (4.35). The evidence of cointegration in each of the model supports the claim of Giles (2013) on mixed integrated series and agrees with previous findings by Dang (2015), Hua (2016) for Vietnam and Onoja, Achike \& Ajibade (2017) for Nigeria. Following the evidence of cointegration in the series, the short run and long run coefficients are estimated to capture the relationship between indices of foreign aid and human capital formation over the study period.

\subsection{Estimation of the ARDL models}

The estimated ARDL models that indicate the short and long run relationships between foreign aid and measures human capital formation are sowed in Tables 3-4. 
Table 3: ARDL estimates for model 1

Dependent Variable: LOG(PED)

Sample: 1990-2017

\begin{tabular}{|c|c|c|c|c|}
\hline \multicolumn{5}{|l|}{ Short run form } \\
\hline Variable & Coefficient & Std. Error & t-Statistic & Prob. \\
\hline DLOG(PED(-1)) & -1.164292 & 0.096306 & -12.089467 & 0.0012 \\
\hline DLOG(ODA) & 0.199301 & 0.083540 & 2.385710 & 0.0971 \\
\hline $\operatorname{DLOG}(\mathrm{ODA}(-1))$ & 0.262448 & 0.055096 & 4.763479 & 0.0176 \\
\hline DLOG(ODA(-2)) & 0.787192 & 0.097713 & 8.056186 & 0.0040 \\
\hline DLOG(ODA(-3)) & 0.571510 & 0.061067 & 9.358691 & 0.0026 \\
\hline DLOG(ODA(-4)) & 0.549394 & 0.060101 & 9.141168 & 0.0028 \\
\hline DLOG(GRT) & -0.087381 & 0.045983 & -1.900275 & 0.1536 \\
\hline DLOG(GRT(-1)) & -0.491322 & 0.053824 & -9.128319 & 0.0028 \\
\hline DLOG(GRT(-2)) & -0.051973 & 0.059184 & -0.878162 & 0.4445 \\
\hline DLOG(GRT(-3)) & -0.910590 & 0.068638 & -13.266524 & 0.0009 \\
\hline DLOG(TCG) & 0.156825 & 0.045567 & 3.441647 & 0.0412 \\
\hline DLOG(TCG(-1)) & 0.132730 & 0.048630 & 2.729395 & 0.0720 \\
\hline DLOG(TCG(-2)) & -0.008923 & 0.057797 & -0.154390 & 0.8871 \\
\hline DLOG(TCG(-3)) & -0.210634 & 0.055748 & -3.778343 & 0.0325 \\
\hline DLOG(TCG(-4)) & -0.442223 & 0.080906 & -5.465883 & 0.0120 \\
\hline CointEq(-1) & -0.463138 & 0.079354 & 5.836355 & 0.0100 \\
\hline \multicolumn{5}{|l|}{ Long run form } \\
\hline Variable & Coefficient & Std. Error & t-Statistic & Prob. \\
\hline LOG(ODA) & 4.289499 & 0.461620 & 9.292269 & 0.0026 \\
\hline LOG(GRT) & -2.611918 & 0.325740 & -8.018402 & 0.0040 \\
\hline LOG(TCG) & 0.829307 & 0.235201 & 3.525952 & 0.0388 \\
\hline $\mathrm{C}$ & -32.41817 & 4.134046 & -7.841754 & 0.0043 \\
\hline R-squared & 0.9048 & & Prob(F-stat.) & 0.000 \\
\hline
\end{tabular}

\section{Source: Author's compilation from the empirical data analysis}

As observed from Table 3, the short run dynamic regression result indicates that the lagged values of public investment in education have significant negative impact on its current value. The result further showed that lagged values ODA exert significant positive impact on public investment in education in the short run. This result coincides with the findings of Hammarstrand \& Sundsmy (2013) and Riddell \& Niño-Zarazúa (2016). Both the first and third lag of broad-based grant has significant negative relationship with public investment in education. The result further revealed that the impact of technical cooperation grant on education investment is mixed. While the contemporaneous value is positively linked to public investments in education, the third and fourth lags of technical cooperation grants are negatively related with public investment in education in the short run. However, the error correction mechanism (ECM) denoted as CointEq(-1) in Table 6 is estimated as -0.463 with probability value of 0.010 . Hence, the ECM is highly significant and has the correct sign. This means that the model can adjust to long run equilibrium position in the event of any short run disequilibrium in the system. The long run result revealed that ODA and technical cooperation grants have significant positive relationship with public investment in education. 1 percent increase in ODA and technical cooperation grants increases public investment in education by 4.289 percent and 0.829 percent respectively. This result is in conjunction with the findings of Mohamed \& Mzee (2017) and Yogo (2017) that foreign aid is helpful in improving educational outcome. The probability value $(0.000)$ of the f-statistic indicates that explanatory variables collectively important in forecasting changes in public investment in education. It was also evident in the coefficient of determination (0.904) that the measures of foreign aid collectively accounted for 90.4 percent of the overall changes in public education expenditure over the study period. Therefore, foreign aid compositions are considered as good sources of human capital development. 
Table 4: ARDL estimates for model 2

Dependent variable: LOG(PHE)

Sample: 1990-2017

\begin{tabular}{|c|c|c|c|c|}
\hline \multicolumn{5}{|l|}{ Short run form } \\
\hline Variable & Coefficient & Std. Error & t-Statistic & Prob. \\
\hline DLOG(ODA) & 1.099277 & 0.308877 & 3.558952 & 0.0162 \\
\hline DLOG(ODA(-1)) & -0.281341 & 0.246948 & -1.139272 & 0.3062 \\
\hline DLOG(ODA(-2)) & -0.412548 & 0.233032 & -1.770351 & 0.1369 \\
\hline $\operatorname{DLOG}(\mathrm{ODA}(-3))$ & 0.243706 & 0.227097 & 1.073135 & 0.3322 \\
\hline DLOG(ODA(-4)) & -0.400308 & 0.239203 & -1.673510 & 0.1551 \\
\hline DLOG(GRT) & -0.820602 & 0.193002 & -4.251774 & 0.0081 \\
\hline DLOG(GRT(-1)) & 0.022988 & 0.167506 & 0.137238 & 0.8962 \\
\hline DLOG(GRT(-2)) & 0.146798 & 0.178641 & 0.821745 & 0.4486 \\
\hline DLOG(GRT(-3)) & -0.252656 & 0.180588 & -1.399070 & 0.2207 \\
\hline DLOG(GRT(-4)) & 0.424390 & 0.224176 & 1.893117 & 0.1169 \\
\hline DLOG(TCG) & 0.715604 & 0.183557 & 3.898546 & 0.0114 \\
\hline DLOG(TCG(-1)) & 0.105535 & 0.233605 & 0.451765 & 0.6704 \\
\hline DLOG(TCG(-2)) & 0.705042 & 0.254552 & 2.769738 & 0.0394 \\
\hline CointEq(-1) & -1.121728 & 0.126292 & -8.882023 & 0.0003 \\
\hline \multicolumn{5}{|l|}{ Long run form } \\
\hline Variable & Coefficient & Std. Error & t-Statistic & Prob. \\
\hline LOG(ODA) & 3.179744 & 0.667262 & 4.765361 & 0.0050 \\
\hline LOG(GRT) & -1.976677 & 0.434076 & -4.553758 & 0.0061 \\
\hline LOG(TCG) & -0.101120 & 0.249621 & -0.405093 & 0.7022 \\
\hline $\mathrm{C}$ & -20.69221 & 3.190454 & -6.485664 & 0.0013 \\
\hline R-squared & 0.920 & & Prob(F-stat.) & 0.000 \\
\hline
\end{tabular}

Source: Author's compilation from the empirical data analysis

The result in Table 4 shows that the contemporaneous value of ODA has positive relationship with public healthcare investment in the short run. 1 percent increase in ODA inflow increases public healthcare investment by 1.099 percent. Similarly, the current value of technical cooperation grant exerts significant positive impact on public healthcare investment increases by 0.716 percent following 1 percent increase in the current inflow of technical cooperation grant. More importantly, the coefficient of ECM is estimated as -1.122 with probability value of 0.000 . This result indicates that the ECM is highly significant and aligns with the hypothesized sign. This implies that the speed of adjustment to long run equilibrium position is very high. The long run result indicates that ODA is positively related to public healthcare investment. The result shows that there is more than proportionate increase in public investment in healthcare to the tune of 3.179 percent following 1 percent increase in ODA. This finding is line with the result of Lu, Cook \& Desmond (2017) and Marty et al. (2017) that foreign aid is effective in boosting public healthcare in the long run. On the contrary, broad-based grant impacted negatively on healthcare investment in the long run. 1 percent increase in broad-base grant causes 1.977 decrease in healthcare investment. The R-squared (0.920) and probability value (0.000) of F-statistic indicate that the model well-fitted for long term forecast.

\subsubsection{Model Evaluation Test Results}

Following the assumptions surrounding the forecast reliability of an estimated regression model, the ARDL models in Tables 6 and 7 were subjected to residual based post-estimation diagnostics in order to validate their reliability. The results are reported in Tables 8-9 and Figures 5-6.

Table 5: Serial correlation and heteroscedasticity tests results for model 1

\begin{tabular}{lcc}
\hline Method of diagnostic test & $\begin{array}{l}\text { Chi-square statistic } \\
\text { (Obs*R-squared) }\end{array}$ & Probability value \\
\hline Breusch-Godfrey Serial Correlation LM Test & 5.905 & 0.215 \\
White heteroscedasticity test & 18.191 & 0.509 \\
\hline
\end{tabular}

Source: Author's compilation from the empirical data analysis

Table 6: Serial correlation and heteroscedasticity tests results for model 2

\begin{tabular}{lcc}
\hline Method of diagnostic test & $\begin{array}{l}\text { Chi-square statistic } \\
\text { (Obs*R-squared) }\end{array}$ & Probability value \\
\hline Breusch-Godfrey Serial Correlation LM Test & 3.408 & 0.065 \\
White heteroscedasticity test & 16.216 & 0.507 \\
\hline
\end{tabular}

Source: Author's compilation from the empirical data analysis 


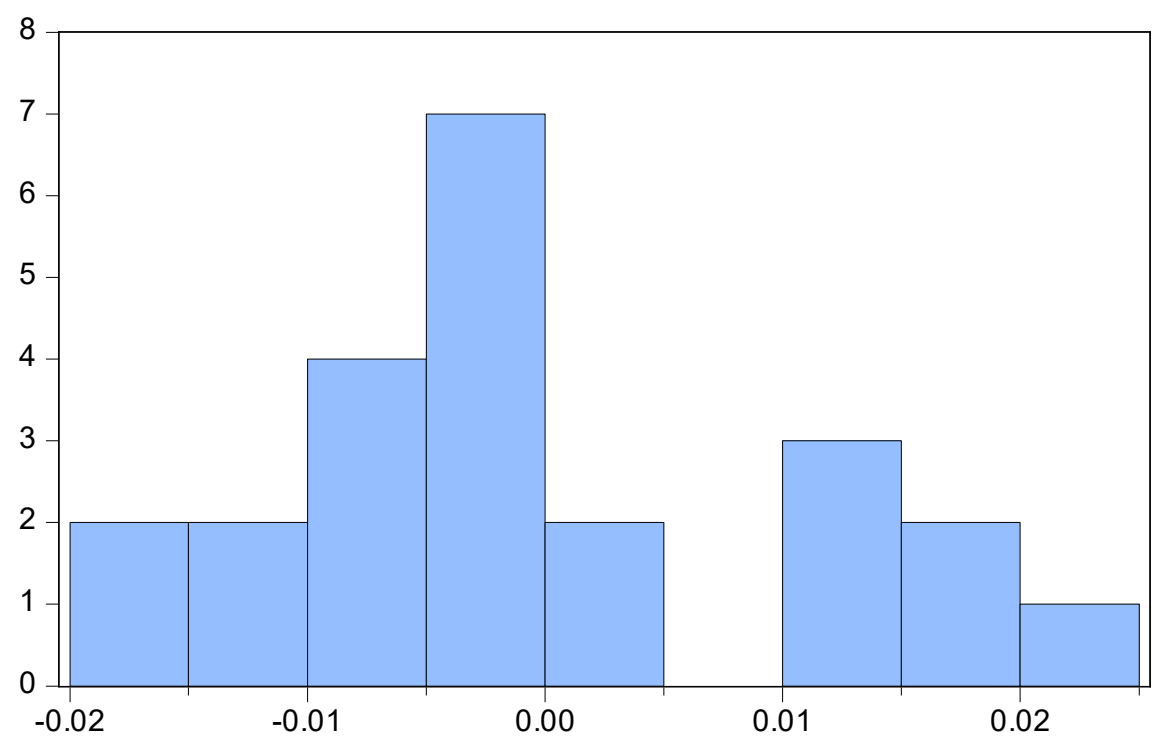

\section{Series: Residuals \\ Sample 19952017 \\ Observations 23}

Mean

Median

$-6.95 e-16$

Maximum

$-0.002072$

Minimum

0.022742

Std. Dev.

$-0.019510$

Skewness

0.011609

Kurtosis

0.425175

Jarque-Bera

2.234733

\section{Probability}

1.254196

Figure 2: Normality test result for model 1

Source: Author's compilation from the empirical data analysis

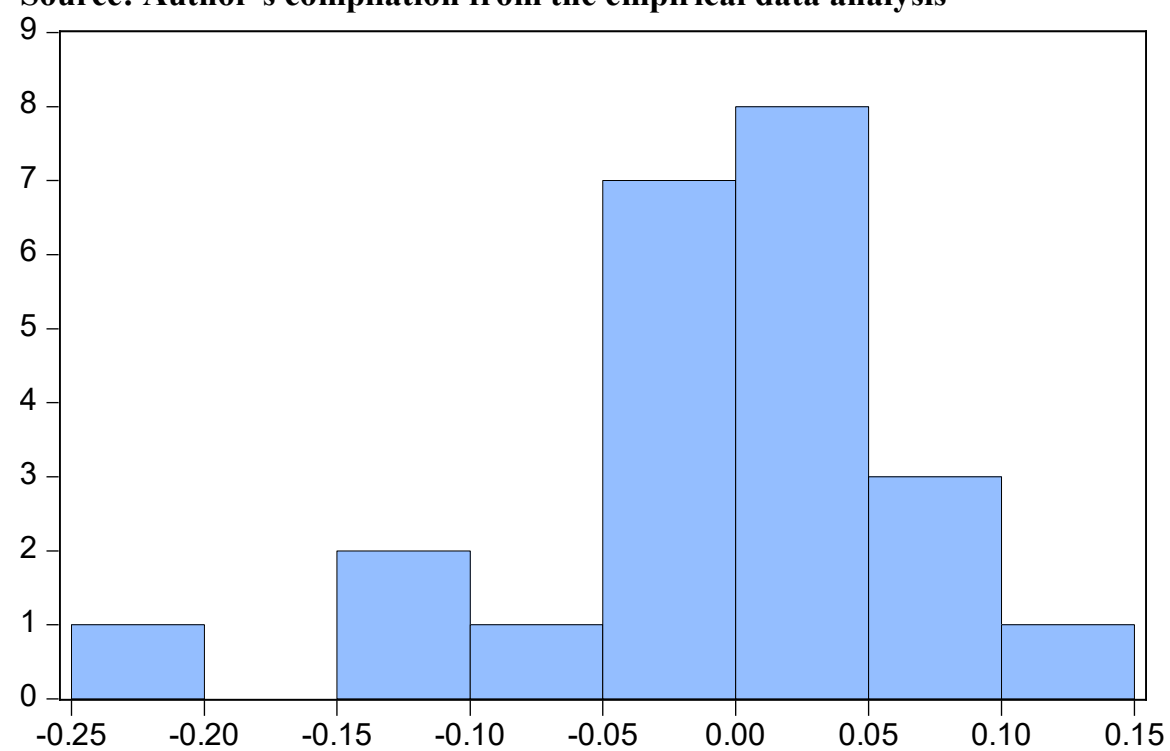

Series: Residuals

Sample 19952017

Observations 23

Mean

2.05e-14

Median

0.008538

Maximum

0.147266

Minimum

$-0.210196$

Std. Dev.

0.074947

Skewness

$-0.738153$

Kurtosis

4.364785

Jarque-Bera

3.873695

Probability

Figure 3: Normality test result for model 2

Source: Author's compilation from the empirical data analysis

To ascertain the forecast reliability of the estimated ARDL models, residual diagnostics tests, especially serial correlation, heteroscedasticity and normality tests were conducted at 5 percent level of significance. It was observed from the results that both models are free from serial correlation. This is because the corresponding probability values of the asymptotically distributed chi-square statistics for the Breusch-Godfrey serial correlation LM test is greater than 0.05 . This provides enough evidence for maintaining the null hypothesis of no serial correlation in the residuals. Again, the chi-square statistics from the White heteroscedasticity test results with probability values above 0.05 indicate that the residuals are homoscedastic. The diagnostics test results further revealed that the residuals are normally distributed given that the probability value of the Jarque-Bera statistics is greater than 0.05 . This necessitated the acceptance of the null hypothesis of normal distribution of the residuals. The outcomes of these tests suggest that the predictive performance of the estimated models can be relied upon.

\section{Conclusion}

The link between foreign aid and human development has remained is a highly debatable topic in both development and international economics literature. Thus, this study offered some insights on the aid effectiveness hypothesis with a focus on human capital formation. Findings indicate that there exists some degree of conflicting results about the nature of relationship between international aid and the underlying measures of human capital formation. 
It was found that ODA has significant positive relationship with public investment in education and healthcare in both short run. Similarly, the results also indicate that the long term impact of technical cooperation grants on public investments in education is positive and significant at 5 percent level. However, broad-based grants negatively influenced public healthcare investment in the long run. Additionally, both the first and third lag of broad-based grant has significant negative relationship with public investment in education. In view of the findings, it is concluded that the effectiveness of foreign aid in driving the process of human capital formation manifests mainly in the long run and ODA has been playing a leading role in the process.

\subsection{Recommendations}

1. Policy makers and donor countries/agencies should prioritize the education sector in the disbursement of foreign aid with a view to achieving the fourth Sustainable Development Goal (SDG) which is to ensure inclusive and quality education for all and promote lifelong learning.

2. Public interest should drive the inflows of ODA and other aid components to the health sector in order to improve the overall healthcare delivery and productivity of the labour force.

3. The Easterly model for aid allocation should be followed by the foreign donor agencies with a focus on small number of tasks in specific fields that offer opportunities for sustained human development and reduce the likelihood of aid fungibility.

\subsection{Suggestion for Further Studies}

Further research efforts should be redirected towards the sectoral allocation of aid, exploring its sector-specific impacts to have a better understanding of the amount available to each sector and their effectiveness over time in order to guide aid policy.

\subsection{Contribution to Knowledge}

This study have shown that ODA has remained outstanding in driving the process of human capital development, having greater and more effective impact on public investments in education and healthcare.

\section{References}

Asiama, J. P., \& Quartey, P. (2009). Foreign Aid and the Human Development Indicators in Sub-Saharan Africa. Journal of Developing Societies, 25(1), 57-83.

Asiama, J. P., \& Quartey, P. (2009). Foreign Aid and the Human Development Indicators in Sub-Saharan Africa. Journal of Developing Societies, 25(1), 57-83.

Asongu, S. A., \& Nwachukwu, J. C. (2018). Increasing foreign aid for inclusive human development in Africa. Social Indicators Research, 138(2), 443-466.

Bacha, E. L. (1990). A three-gap model of foreign transfers and the GDP growth rate in developing countries. Journal of Development economics, 32(2), 279-296.

Bakare, A.S. (2011). The Macroeconomic Impact of Foreign Aid in Sub-Saharan Africa: The Case of Nigeria. Business and Management Review, 1(5).

Becker, G.S. (2011). The Concise Encyclopedia of Economics Human Capital. http//:www.econlib.org/library/Enc/Human Capital.html. Retrieved on15/7/20.

Breusch, T. S. (1978). Testing for Autocorrelation in Dynamic Linear Models. Australian Economic Papers. 17: $334-355$

Burnside, C., \& Dollar, D. (2000). Aid, policies, and growth. American economic review, 90(4), 847-868.

Cashel-Cordo, P. and Craig, S.G. (1990). The public sector impact of international resource transfers. Journal of Development Economics, 32,17-42

Chenery, H. B., and Bruno, M. (1962). Development Alternatives in an Open Economy: The Case of Israel," Economic Journal, 72: 79-103.

Chenery, H.B., Strout, A.M. (1966). Foreign Assistance and Economic Development. American Economic Review, 56(4), 679-733.

Cohen, L ., Manion, L. \& Morison, K. (2000). Research Methods in Education. London: Routledge Falmer.

Collier, P. (2007): "The Bottom Billion: Why the Poorest Countries Are Failing and What Can Be Done About it. New York: Oxford University Press

Conchesta, K. (2008). Foreign Aid and Economic Growth: the Case of Tanzania. Institute of Social Studies. (Unpublished material).

Conlisk, J., \& Huddle, D. (1969). Allocating foreign aid: An appraisal of a self-help model. The Journal of Development Studies, 5(4), 245-251.

Creswell, J. W. (2003). Research Design: Qualitative, quantitative and mixed methods approaches, London: Sage.

Domar, E. D. (1946). Capital expansion, rate of growth, and employment. Econometrica, Journal of the Econometric Society, 137-147. 
Easterly, W. (1999). The ghost of financing gap: how the Harrod-Domar growth model still haunts development economics. The World Bank.

Easterly, W. (2003), Can Foreign Aid Buy Growth? Journal of Economic Perspectives, 17(3).

Easterly, W. (2006). The White Man's Burden. London: Penguin.

Ewubare, D. B. (2018). Economic Planning and Human Capital Development in Nigeria. International Journal of Business Management and Finance Research, 1(1), 9-20.

Gillanders, R. (2016). The effects of foreign aid in Sub-Saharan Africa. The Economic and Social Review, 47(3, Autumn), 339-360.

Godfrey, L. G. (1978). Testing Against General Autoregressive and Moving Average Error Models when the Regressors Include Lagged Dependent Variables". Econometrica,46: 1293-1301.

Griffin, K. \& Enos, J.L. (1970). Foreign Assistance: Objectives and Consequences. Economic Development and Cultural Change. 18, 313-27.

Hammarstrand, L. andSundsmy, S.(2013) Aid Effectiveness on Living Standards: How Does Aid Affect Human Development Index (HDI) in SubSaharan Africa? Unpublished Bsc. Thesis.

Harod, R. (1939). An Essay in Dynamic Theory. Economic Journal 44, 14-33.

Hua, Z. J. (2016). ARDL Bounds Testing Approach to Cointegration: Relationship International Trade Policy Reform and Foreign Trade in Vietnam. International Journal of Economics and Finance, 8(8), 84.

Ishnazarov, D., \& Cevik, N. (2017). Foreign Aid Effectiveness In Oic Member Countries: Beyond Economic Indicators. International Journal of Economics, Management and Accounting, 25(2), 315.

Kanayo, O. (2013). The impact of human capital formation on economic growth in Nigeria. Journal of Economics, $4(2), 121-132$.

Kerlinger, F.N., \& Rint, N. (1986) Foundations of Behaviour Research. London: Winston Inc.

Knack, S., \& Keefer, P. (1997). Does social capital have an economic payoff? A cross-country investigation. The Quarterly journal of economics, 112(4), 1251-1288.

Kucharčíková, A. (2011). Human capital-definitions and approaches. Human Resources Management \& Ergonomics, 5(2), 60-70.

Lancaster, C. (2006). Foreign aid: Diplomacy, Development, Domestic Politics. Chicago, IL: University of Chicago Press.

Lu, C., Cook, B., \& Desmond, C. (2017). Does foreign aid crowd out government investments? Evidence from rural health centres in Rwanda. BMJ global health, 2(3), e000364.

Manty Jones, Y. (2013). Testing the foreign aid-led growth hypothesis in West Africa. Birkbeck University Working Papers in Management,

Maqsood, F., \& Ullah, S. (2014). Foreign Aid Volatility and Socio-Economic Dimensions of Human Development Index: A Case Study of Pakistan. Pakistan Journal of Social Sciences (PJSS), 34(1).

Marty, R., Dolan, C. B., Leu, M., \& Runfola, D. (2017). Taking the health aid debate to the subnational level: the impact and allocation of foreign health aid in Malawi. BMJ global health, 2(1), e000129.

McGillivray, M. (2005). Is aid effective?. Helsinki: World Institute for Development Economics Research (draft), ca. February (mimeo).

McGillivray, M. and Morrissey, O. (2000). Aid Fungibility in Assessing Aid: Red Herring or True Concern? Journal of International Development, 12(1),413-428.

Mohamed and Mzee (2017). Foreign Aid and Human Development: A Quantile Regression Approach. International Journal of Economics, Management and Accounting, 25(1), 27.

Moreira, S. B. (2005). Evaluating the impact of foreign aid on economic growth: A cross-country study. Journal of Economic Development, 30(2), 25-48.

Mosley, P. (1986). Aid-effectiveness: The Micro-Macro Paradox. Ids Bulletin, 17(2), 22-27.

Najeb, M. (2014). A contribution to the theory of economic growth: Old and New. Journal of Economics and International Finance, 6(3), 47.

Nelson, C. R., \& Plosser, C. R. (1982). Trends and random walks in macroeconmic time series: some evidence and implications. Journal of monetary economics, 10(2), 139-162.

Newey, W. K., \& West, K. D. (1987). A simple, positive semi-definite, heteroskedasticity and autocorrelationconsistent covariance matrix. Econometrica, 55(3), 703-708.

Omoniyi, L. G., \& Olawale, A. N. (2015). An Application of ARDL Bounds Testing Procedure

Ozigbu, J. C. (2018). Evaluating the hypothesis of aid fungibility: A focus on human development in Nigeria. Journal of Economics and Sustainable Development, 9(14), 150-161.

Pesaran, M. H. and Shin, Y. (1999). An autoregressive distributed lag modelling approach to cointegration analysis. Chapter 11 in S. Strom (ed.), Econometrics and Economic Theory in the 20th Century: The Ragnar Frisch Centennial Symposium. Cambridge University Press, Cambridge.

Pesaran, M. H., Shin, Y., \& Smith, R. J. (2001). Bounds testing approaches to the analysis of level relationships. Journal of applied econometrics, 16(3), 289-326. 
Pettersson, J. (2007). Foreign sectoral aid fungibility, growth and poverty reduction. Journal of International Development, 19(8), 1074-1098.

Phillips, P. C., \& Perron, P. (1988). Testing for a unit root in time series regression. Biometrika, 75(2), 335-346.

Rady, T. (2012). Foreign aid and development: What can developing nations learn. Journal of Economics and Economic Education Research, 13(3), 123.

Riddell, A., \& Niño-Zarazúa, M. (2016). The effectiveness of foreign aid to education: What can be learned?. International Journal of Educational Development, 48, 23-36.

Rotarou, E., \& Ueta, K. (2009). Foreign Aid and Economic Development. The Kyoto Economic Review, 78(2), $157-189$.

Sachs, J. D. (2005). The End of Poverty: Economic Possibilities of Our Time. New York: Penguin Press.

Snowdon, B. (2009). The Solow model, poverty traps, and the foreign aid debate. History of Political Economy, 41(1), 241-262.

Staicu, G., \& Barbulescu, R. (2017). A Study of the Relationship between Foreign Aid and Human Development in Africa. In International Development. InTech.

Tang, K. B., \& Bundhoo, D. (2017). Foreign Aid and Economic Growth in Developing Countries: Evidence from Sub-Saharan Africa. Theoretical Economics Letters, 7(05), 1473.

Taylor, L. (1994). Gap models. Journal of Development Economics, 45(1), 17-34.

Türsoy, T. (2017). Causality between stock prices and exchange rates in Turkey: Empirical evidence from the ARDL bounds test and a combined cointegration approach. International Journal of Financial Studies, 5(1), 8.

UNDP (2016). Human Development Report. Canada: Lowe-Martin Group.

White, H. (1980). A heteroskedastic-consistent covariance matrix estimator and a direct test of heteroskedasticity. Econometrica, 48, 817-838.

Yogo, T. U. (2017). Assessing the Effectiveness of Foreign Aid in the Education Sector in Africa: The Case of Primary Education. African Development Review, 29(3), 389-402. 